\title{
Saudi Female EFL Learners and Collaborative Writing: Attitudes and Challenges
}

\author{
Nada Abdulaziz Alkhalaf \\ Department of English Language and Translation, College of Arabic Language and Social Studies, Qassim University, \\ Qassim, Saudi Arabia
}

\begin{abstract}
Writing skills are important skills that must be learned to express one's thoughts and ideas. Therefore, several strategies were used in writing classes to enhance learners' writing skills, one of which is collaborative writing. A number of studies reported many advantages for this strategy in terms of the quality of the produced texts and the improvements in students' writing skills. The present study aimed at investigating the attitude of Saudi female EFL learners toward collaborative writing and the challenges/problems that may arise during the activity. It adopted a quantitative approach in which 50 Saudi female EFL learners answered a questionnaire about their experience in writing collaboratively and the problems they encountered during the activity. The findings have shown that the learners have a positive attitude toward collaborative writing. However, there were some problems in terms of students' behavior, assessment and time management. These findings encourage writing teachers to use this strategy in their classes. In addition, the findings encourage teachers and researchers to address the problems reported in the study.
\end{abstract}

Index Terms - collaborative writing, collaborative writing attitude, collaborative writing problems, second language writing

\section{INTRODUCTION}

Writing skills are one of the important skills that language learners must learn (Koura \& Zahran, 2017), and they are challenging and require a lot of practice to master (Richard, 1990). Therefore, language teachers try to employ different strategies to help learners improve, one of which is collaborative writing (Ghufron \& Hawa, 2015; Supiani 2017). The effect of collaborative writing has been investigated by a number of studies (e.g., Storch \& Wigglesworth, 2007). However, few studies have explored learners' attitudes toward collaborative writing (e.g., Shehadeh, 2011) and the problems they may encounter during the task (e.g., Lin \& Maarof, 2013).

\section{A. The Study Problem}

The present study aims to investigate the attitude of Saudi female EFL learners toward collaborative writing and the challenges/problems they may face during the activity. Although collaborative writing is not widely used in writing courses in Saudi Arabia, based on the literature, it is anticipated that the learners will have a positive attitude toward writing collaboratively. However, some problems are expected to arise in terms of assessment and students' collaboration. The findings of this study will be valuable for writing teachers. If the hypotheses are true, teachers will be encouraged to use this strategy in their writing classes. In addition, teachers and researchers will be encouraged to address the problems that the students face during the activity.

\section{B. The Research Questions}

The study sought to answer the following questions:

1. What is the attitude of Saudi female EFL learners toward collaborative writing?

2. What are the challenges/problems that may arise during collaborative writing?

\section{LITERATURE REVIEW}

\section{A. Learning as a Social Process}

Based on sociocultural theory, humans' learning always happens in a social context (Vygotsky, 1978). Vygotsky (1978), the pioneer of this theory, emphasized the importance of social interaction in the development of mental abilities. By participating in social activities, and through interaction with others in their society, individuals develop their cognition (Ghufron \& Hawa, 2015).

To explain how social interaction results in learning, the sociocultural theory proposes that through interaction with a more knowledgeable person, a learner can perform a task that he is unable to carry out by himself (Ellis, 2008). Then, gradually the learner internalizes what he has learned so that he can do the task alone (Ellis, 2008). This form of dialogic assistance is called scaffolding and is considered as one of the main constructs in sociocultural theory (Ellis, 2008). 
Scaffolding in sociocultural theory is linked to what is called the zone of proximal development, which is defined as the distance between the current level of development and the potential level of development achieved under guidance or when collaborating with others (Vygotsky, 1978). Vygotsky (1978) differentiated between what an individual can achieve by himself and what he can achieve with the assistance of others. Through social interaction, individuals construct the zone of proximal development needed to perform a task (Ellis, 2008).

\section{B. Collaborative Learning in the Classroom}

Collaborative learning is considered an educational approach (Laal \& Ghodsi, 2012) that is based on the social theory of learning (Vygotsky, 1978). It involves two or more students making decisions, sharing responsibilities, and working together to learn (Dillenbourg, 1990, as cited in Hernández, 2012). During collaborative learning, knowledge is socially constructed (Chandra, 2015). By working together, students can help each other in completing a task, creating a product, or solving a problem (Laal \& Ghodsi, 2012). Furthermore, Laal and Ghodsi (2012) found that collaborative learning creates a positive learning environment in which students provide support for each other. They also found that collaborative learning decreases students' anxiety and increases their self-confidence and their involvement in the learning process. Moreover, research has shown that collaborative learning stimulates critical thinking and problemsolving skills (Laal \& Ghodsi, 2012). In addition, collaborative learning develops students' leadership skills, selfmanagement, and communication skills (Chandra, 2015). It also increases students' awareness of individual differences and prepares them for real-life situations in which they have to accept and respect diversity (Chandra, 2015).

\section{Collaboration in Second Language Learning}

According to Shehadeh (2011), there is an increase in the use of collaborative learning in language classrooms. This can be due to the belief that collaboration is important in language learning and teaching (Ellis, 2003). Isnaini (2017) argued that collaborative work can be an effective tool that contributes to better language learning. One benefit of collaborative language learning is that it provides language learners with the required input and output (Zhang, 2010). Swain (1985) stressed the importance of producing output during collaborative tasks on students' language skills. Collaborative writing encourages students to pay more attention to how they should express their ideas and how to convey what they mean (Swain, 1985). According to Zhang (2010), to ensure that their message is clear, students may use different ways to express their ideas, which provides more comprehensible input for other members in the group. Moreover, collaborative work enables learners to help each other to produce a precise message (Kowal \& Swain, 1994). This can be linked to the concept of the zone of proximal development (Isnaini, 2017), in which a learner moves from what he cannot do alone to what he can achieve with the assistance of others (Ellis, 2008).

Research has also investigated the effect of cooperative work on second language proficiency (Liang, Mohan, \& Early, 1998). Sharon, Kussell, Bejarano, and Pelege's (1984) research found that students' performance in a listening comprehension test and their overall proficiency in their second language improved because of collaborative learning. Another advantage of collaborative work in second language classrooms is that it creates a relaxed atmosphere, which increases students' motivation (Brown, 1994). Students can practice what they will say with their groups before answering in front of the class, which reduces anxiety and which in turn may result in more participation (Crandall, 1999) and, consequently, an increase in students' self-esteem (Zhang, 2010). In addition, collaborative work may enable learners to practice the new items in the curriculum, which develops both their social language and academic language (Zhang, 2010).

\section{The Social Aspect of Writing}

According to Dueraman (2012), social constructionists believe that writing is a social process that occurs in a social context to achieve particular purposes. Writing is the result of writers' needs to express themselves and communicate with others in their society (Ramírez, 2007, as cited in Chala \& Chapeton, 2012). Moreover, the beliefs, feelings, and experiences of writers are shaped through their interaction with people in their society and culture (Castro \& Chala, 2013). In fact, Dueraman (2012) argued that writing is one of the higher mental functions that Vygotsky (1978) found to develop in interaction.

Elbow (2000) stressed that "all writing is social" (p. 259), and Casanave (2004) pointed out that writing involves interaction with different audiences. These audiences affect the style of the text (Wheaton College, n.d). In same line, Deane, Odendah, Quinlan, Fowles, Welsh, and Tatum (2008) pointed out that the way a text is structured and received is also influenced by the community of practice to which the writer belongs.

\section{E. Writing in EFL Classes}

Writing is a significant skill for EFL learners (Koura \& Zahran, 2017), because it facilitates foreign language acquisition and provides students with better career opportunities (Harmer, 2007, as cited in Bueno-Alastuey \& Larumbe, 2017). However, learning writing skills is considered a difficult task for both native speakers and foreign language learners (Richard, 1990). Moreover, the degree of difficulty increases in countries where English is a foreign language and is not practically used (Salma, 2015). Therefore, many teachers find it challenging to teach writing in EFL classes (Hidayati, 2018). Other factors such as classroom environment, outdated courses (Fareed, Ashraf, \& Bilal, 2016), and the use of traditional teaching approaches may affect students' learning (Bilal, Tariq, Din, Latif, \& Anjum, 2013). 
In addition, students may lack motivation due to the difficulty that they experience in composing a text (Tessema, 2005). They may struggle not only with vocabulary and grammar but also with organizing their ideas (Tessema, 2005). As a response to these challenges, Bilal, et al. (2013) suggested that writing teachers need to be trained properly. They also need to work on motivating their students to develop their writing skills (Bilal, et al., 2013; Tessema, 2005).

\section{F. Collaborative Second Language Writing}

As a response to the difficulties of teaching and learning writing, some teachers employ collaborative writing to improve students' writing skills (Ghufron \& Hawa, 2015; Supiani, 2017). Collaborative writing was first used as a strategy in writing classes by Bruffee (1984). It can be defined as a process in which a pair or a group of students collaborates in producing a written text (Supiani, 2017). This means that students must cooperate in all the writing stages from brainstorming to paper editing (Supiani , 2017). In literature, this method has been linked to sociocultural theory, and particularly to the zone of proximal development, in which students can develop with the help of others (Nurfaidah, 2018). During the activity, students are engaged in what Swain (2000) called collaborative dialogue, which refers to the dialogue between speakers who are involved in constructing knowledge and producing a message, meaning that students can learn to use language while interacting with others during the task (Elola \& Oskuz, 2010).

Research has shown that collaborative writing has many advantages in EFL classes (Elola \& Oskuz, 2010). It enables learners to reflect on their use of language (Elola \& Oskuz, 2010) and solve language-related issues (Storch \& Wigglesworth, 2007). Moreover, it integrates the four skills: listening and speaking (through interaction) and reading and writing (in completing the task) (Bueno-Alastuey \& Larumbe, 2017). In addition, research has shown that collaborative writing increases students' self-confidence and reduces their anxiety (Supiani, 2017). Foster (1998, as cited in Megnafi, 2015) argued that it also improves students' creativity and increases their motivation. Similarly, Tarmizi and Cheung (2017) found that the improvement in students' writing motivated them to write.

Moreover, collaborative writing allows students to see how others think and how ideas are created (Supiani, 2017). Studies have shown that collaborative writing results in higher-quality texts (Storch, 2005), because dialogue encourages the co-construction of knowledge (Storch, 2002; Swain \& Lapkin, 1998).

Other studies have shown that collaborative writing has a positive effect on students' achievement and test results (Aminloo, 2013). Weinstein and Bearison (1985, as cited in Tarmizi \& Cheung, 2007) found that collaborative writing is beneficial for both students with high proficiency levels and students with low proficiency levels. Students with low proficiency levels in particular can develop the intended skills (Tarmizi \& Cheung, 2017) as well as the organizational skills from their interaction with their peers (Naghdipour, 2016, as cited in Tarmizi \& Cheung, 2017).

\section{G. Studies on Learners' Attitudes toward Collaborative Writing}

Some studies were carried out to explore students' attitudes toward collaborative writing (e.g., Al Ajmi \& Ali, 2014; Gökçe, 2001). According to Tarmizi and Cheung (2017), studies have found that students have a positive attitude toward collaborative writing tasks because they believe they could help improve their language. Farrah (2011), for example, reported that students in his study were positive toward collaborative writing. Gökçe (2001) explored students' attitudes about collaborative writing after the first collaborative writing activity and once more after the fourth collaborative writing task. She found that students had a neutral attitude first but their attitude became positive after engaging in four collaborative tasks. Another study was carried out by Storch (2005), which concluded that, overall, students found that collaborative writing was a good experience. Similarly, Louth, McAllister, and McAllister (1993) pointed out that the participants in their study felt more satisfied with their writing in the collaborative activity.

\section{H. Problems in Collaborative Writing}

As Chisholm (1990) stated, problems will arise in collaborative tasks. Some students are unwilling to spend their time and effort on a group project (Chisholm, 1990). Others may be shy, lazy, or reluctant, or they may simply not like participating in group activities (Chisholm, 1990). In addition, Kraut, Egido, and Galegher (1987) mentioned that problems "in forming and maintaining personal relationships and completing tasks" (p. 31) might arise at all the stages in the collaborative task. Similarly, Tarmizi and Cheung (2017) found that the relationship between members of the group may affect their work. They noted that some students might find it difficult to participate in a group activity with unfamiliar people. Furthermore, problems may also occur because of students' different levels or standards (Narayan \& Johnson, n.d.).

Shea (1995) noted some potential issues in students' behavior during collaborative work. Some dominant members may do all the work, while others may show a negative attitude toward the task because they feel that their score will be affected by other students' work (Shea, 1995). Other members may be irresponsible and depend on others to do their work (Shea, 1995). In addition to these issues, sometimes it might be difficult to find suitable times for meetings (Shea, 1995).

\section{Methodology}

\section{A. Subjects}


The subjects in this study were 50 Saudi female EFL learners, enrolled in an IELTS preparation course at Qassim University. The subjects aged between 24-29 years old. They all have acquired bachelor's degree in different majors (e.g., Mathematics, Translation, Computer Science, English literature, and Physics). They work as teaching assistants at Qassim University and are taking the IELTS preparation course prior to enrollment in master's programs. Based on a placement test, they were divided into three groups based on their level of English (beginner, intermediate, advanced) and all the three groups had four writing sessions a week.

\section{B. Instrument}

The instrument used in this study was a questionnaire comprised three Likert-types items asking the participants whether they agree or disagree to a series of statements (see Appendix A). The questionnaire included 17 items to elicit the participants' attitudes towards collaborative writing and the problems they faced. It is divided into two sections: the first section (statement 1-11) explored the subjects' attitude toward writing in groups whereas the second section (statement 12-17) aimed to identify the problems that the students encountered during the activity.

The questionnaire is based on previous studies: Abdel \& Farrah (2015) (statement 1,2,3,8,9,11), Gökçe (2001) (statement 4,5,10,12,16).

\section{Procedure}

Throughout the semester, all the subjects engaged in at least one collaborative writing task in which they had to cooperate to write a well-organized essay. They were divided into groups of three or four students. Sometimes, the participants were given the chance to form their group, while in others, the teachers form the group themselves. At the end of the 15-week semester, the participants were asked to answer a questionnaire to investigate their attitude toward collaborative writing and the challenges/problems they encounter during the task.

\section{RESULTS}

The present study aimed at investigating the attitude of Saudi female EFL learners toward collaborative writing. Furthermore, it sought to identify the challenges/problems that arise during the collaboration. Therefore, the research questions are:

1. What is the attitude of Saudi female EFL learners toward collaborative writing?

2. What are the challenges/problems that may arise during collaborative writing?

To answer the research questions, 50 subjects were asked to answer a questionnaire about their experience in writing collaboratively. The following table shows the learners' responses:

TABLE 1

RESPONSES TO THE QUESTIONNAIRE ABOUT COLLABORATIVE WRITING

\begin{tabular}{|c|c|c|c|}
\hline Statement & Agree & Neutral & Disagree \\
\hline $\begin{array}{l}\text { 1. Collaborative writing is an effective strategy that results in better, more accurate and } \\
\text { complex essays. }\end{array}$ & $66 \%$ & $28 \%$ & $6 \%$ \\
\hline $\begin{array}{l}\text { 2. Collaborative writing makes the task more enjoyable and interesting, and motivates to } \\
\text { write. }\end{array}$ & $72 \%$ & $18 \%$ & $10 \%$ \\
\hline 3. Expressing my ideas to the group improves my communication and negotiation skill. & $80 \%$ & $14 \%$ & $6 \%$ \\
\hline $\begin{array}{l}\text { 4. Collaborative writing helps me learn how to plan, organize, and structure the essay more } \\
\text { effectively. }\end{array}$ & $74 \%$ & $22 \%$ & $4 \%$ \\
\hline 5. Collaborative writing helps in improving my writing skill in general. & $56 \%$ & $30 \%$ & $14 \%$ \\
\hline $\begin{array}{l}\text { 6. Collaborative writing helps in understanding and considering multiple viewpoints on a } \\
\text { particular topic. }\end{array}$ & $94 \%$ & $4 \%$ & $2 \%$ \\
\hline 7. Collaborative writing helps in constructing a strong argument. & $66 \%$ & $30 \%$ & $4 \%$ \\
\hline 8. Collaborative writing helps me verbalize and explain my ideas. & $78 \%$ & $14 \%$ & $8 \%$ \\
\hline $\begin{array}{l}\text { 9. Collaborative writing stimulates critical thinking skills (through commenting on others' } \\
\text { ideas). }\end{array}$ & $84 \%$ & $14 \%$ & $2 \%$ \\
\hline $\begin{array}{l}\text { 10. Collaborative writing helps in improving grammatical accuracy and learning } \\
\text { vocabulary. }\end{array}$ & $84 \%$ & $12 \%$ & $4 \%$ \\
\hline 11. Collaborative writing helps me receive useful feedback. & $80 \%$ & $14 \%$ & $6 \%$ \\
\hline 12. In collaborative writing, everyone performs an equal amount of work. & $10 \%$ & $34 \%$ & $56 \%$ \\
\hline 13. It is unfair that all the members get the same grade. & $48 \%$ & $26 \%$ & $26 \%$ \\
\hline 14. Some members do not accept opposing opinions. & $70 \%$ & $22 \%$ & $8 \%$ \\
\hline $\begin{array}{l}\text { 15. Some members control the discussion without giving others an opportunity to explain } \\
\text { their ideas. }\end{array}$ & $72 \%$ & $14 \%$ & $14 \%$ \\
\hline 16. Collaborative writing consumes a lot of time. & $40 \%$ & $22 \%$ & $38 \%$ \\
\hline $\begin{array}{l}\text { 17. Members discuss their ideas in Arabic, which decreases the chances of improving } \\
\text { communication skill. }\end{array}$ & $66 \%$ & $28 \%$ & $6 \%$ \\
\hline
\end{tabular}


As shown in table 1 above, the subjects responded positively to almost all the statements. Based on their responses, collaboration has a positive impact on the quality of the produced text (statement 1,6,7,8). In fact, 66\% of the subjects agreed that writing in groups results in better, more accurate and complex essays, whereas only $6 \%$ disagreed with this statement. Furthermore, 94\% found that that collaborative writing helped them understand different viewpoints regarding the topic, which results in constructing a strong argument. Moreover, $78 \%$ agreed that writing collaboratively helps them in verbalizing and explaining their ideas.

In addition, the subjects' responses show that writing in groups has a positive influence on their writing skills (statement 2.4,5,10,11). As shown above, 56\% of the subjects claimed that collaborative writing helps in improving their writing skills in general. In terms of text organization and planning, 74\% agreed that writing collaboratively helps them in learning these skills. Moreover, the subjects' responses suggest that collaborative writing contributed to the development of their grammatical and lexical resources (84\% agreed, whereas only $4 \%$ disagreed). Furthermore, according to $80 \%$ of the subjects, the feedback that they received during the discussion was useful. Lastly, $72 \%$ agreed that collaboration makes the task more interesting and enjoyable.

In terms of the effect of collaborative writing on students' skills in general (statement 3-9), most of the learners (80\%) claimed that collaborative writing improved their communication and negotiation skills and stimulated their critical thinking skills $(84 \%)$.

Concerning the challenges/problems of collaborative writing (statement 12,13,14,15), more than half of the subjects $(56 \%)$ claimed that members of the group do not contribute equally to the texts; therefore, $48 \%$ believe that it is unfair that all the members obtain the same score. Moreover, $72 \%$ agreed that some dominant members control the discussion, while $70 \%$ claimed that some members may not accept opposing opinions. These can be serious issues that may hinder the intended effect of collaborative writing.

Another problem that may decrease the positive impact of collaborative writing is the students' use of their mother tongue (Arabic) in the discussion (statement 17). In this study, 66\% of the subjects agreed that group members used Arabic during the task, which decreases the chances of improving their skills.

Lastly, in term of time management (statement 16), as shown above, $40 \%$ of the subjects claimed that writing collaboratively consumes a lot of time, whereas $38 \%$ disagreed that it is time consuming. This disagreement between the subjects can be explained in a number of reasons (see Discussion).

\section{DISCUSSION}

The findings of the study reveal the positive attitude of Saudi female EFL learners toward collaborative writing. This is in line with the findings of Storch's (2005) study, in which 16 out of 18 learners showed a positive attitude toward writing in pairs or groups. The same conclusion was also reached by Shehadeh (2011), who found that most of the participants had a positive perception toward collaborative writing. They claimed that they enjoyed the collaborative task and benefited from it. Similarly, Dobao and Blum (2013) reported that the subjects in their study showed a positive attitude toward writing in pairs and in small groups.

\section{A. The Effect of Collaborative Writing on the Quality of the Text}

The data from the questionnaire showed that more than half of the subjects believe that collaborative writing has a positive influence on the quality of their final product. They found that the texts that were written by a group were complex and more accurate. The reason could be that in collaborative writing, students engage in discussions, brainstorm together, and share knowledge, which result in more ideas (Ghufron \& Hawa, 2015). Moreover, discussions enable them to understand different opinions about a particular topic (Choi, 2008), which helps them with constructing strong arguments. In addition, the increase in accuracy can be the result of students' collaboration in revising and editing the text (Aminloo, 2013). This is in line with Ghufron and Hawa (2015), who pointed out that collaborative writing improves the text quality because it employs the strengths of the group members. The same conclusion was reached by Shehadeh (2011), who stated that texts written by a group were better in terms of organization, content, and vocabulary. Furthermore, Wigglesworth and Storch (2009) found that collaborative writing did influence the grammatical accuracy but not the complexity or the length of the text. This could be due to the discussion, which leads to the correct outcome (Wigglesworth \& Storch, 2009). Wu (2015) stressed that sometimes the effect of collaborative writing may vary from one language area to another due to students' low levels of proficiency in the foreign language, which prevents them from assisting each other, which may affect the quality of the text.

The majority of the subjects also pointed out that collaborative writing helped them learn how to plan and organize their text more effectively. This can be due to the interaction between students with different proficiency levels, which may enable students with low proficiency levels to learn organizational skills from more capable peers and apply them during the task (Naghdipour, 2016, as cited Tarmizi \& Cheung, 2017). Studies have also shown that texts written by a group of learners were better in terms of topic development (Aminloo, 2013) and organization (Shehadeh, 2011).

\section{B. The Effect of Collaborative Work on Students' Language Skills}

As shown by the results of the questionnaire, most of the subjects agreed that collaborative writing tasks improved their language skills, increased their vocabulary, and improved their grammatical accuracy. One reason for this 
improvement could be that integrating listening and speaking facilitate students' foreign language (Bueno-Alastuey \& Larumbe, 2017), while writing in groups improved their writing in terms of vocabulary and grammar (Dobao, 2012). These findings are consistent with many studies that have stressed the importance of collaborative work in second language learning (Ellis, 2003; Shehadeh, 2011).

According to Al Ajmi and Ali (2014), during collaborative tasks, students learn through what is known as "languaging." Languaging refers to what happens during students' interactions when they write collaboratively (Al Ajmi \& Ali, 2014). During collaborative tasks, the discussion of language enhances students' learning (Wigglesworth \& Storch, 2012). Students may discuss their choice of a particular lexical category or their use of a specific grammatical rule (Al Ajmi \& Ali, 2014), which will enhance their learning (Tarmizi \& Cheung, 2017; Wigglesworth \& Storch, 2012). In addition, collaborative tasks provide opportunities for students to use the second language (Storch \& Aldosari, 2010) and to reflect on its use (Elola \& Oskuz, 2010; Storch \& Wigglesworth, 2007).

\section{The Effect of Collaborative Writing on Students' Motivation}

In the questionnaire, most of the students agreed that collaboration made the task more interesting and enjoyable, which motivates them to write. The same conclusion was reached by Supiani (2017). Some studies have suggested that this increase in students' motivation is due to the improvement in their texts and in their writing skills in general (Tarmizi \& Cheung, 2017). However, it should be noted that factors such as low-proficiency level, lack of selfconfidence, passive members, and personal preference might affect students' motivation (Wu, 2015), which may reduce the positive influence of collaborative writing .

\section{The Effect of Peer Feedback}

Another finding of the present study is that the majority of the subjects stated that they learned and benefited from the discussion with their peers and that they agreed that collaborative writing enabled them to receive valuable feedback. This is consistent with Wigglesworth and Storch's (2012) study, which concluded that when learners write collaboratively, their learning is enhanced by discussion and scaffolding. Similarly, Tarmizi and Cheung (2017) pointed out that collaboration allows students to give feedback to each other, which improves their vocabulary, provides them with ideas, and enhances their learning. Additionally, students with a low proficiency level might be able to improve the target skills with the assistance of other capable peers (Tarmizi \& Cheung, 2017).

Furthermore, $82 \%$ of the subjects reported that collaborative writing stimulates critical thinking skills. The same conclusion was reached by Ghufron and Hawa (2015), who suggested that students' critical thinking can improve after writing collaboratively. During the discussion, students express their opinions and comment on others', which gives them the opportunity to think critically. However, this can only happen when students are not shy or reluctant to comment on their peers' ideas. Therefore, teachers must encourage their students to discuss their ideas freely.

\section{E. Problems in Collaborative Writing}

The data from the questionnaire showed that there are some problems that may hinder the positive effect of collaborative writing.

1. Students' behavior. More than half of the subjects agreed that a serious issue in collaborative writing is that some members are unwilling to accept opposing opinions. Because of continued disagreement, some students may not be motivated to engage in collaborative writing tasks (Bremner, 2010, as cited in Tarmizi \& Cheung, 2017).

In addition, almost half of the subjects stated that in collaborative writing, the group members do not contribute equally. Davies (2009) calls passive members “free-riders". Free-riding could be the reason why the subjects responded positively when asked whether it was unfair that all the members obtained the same score. Similarly, Al Ajmi and Ali (2014) stressed that some students' negative attitudes toward collaborative writing is because unproductive members obtain marks regardless of their lack of contribution.

The majority of the subjects reported that some members controlled the discussion without providing others with opportunities to explain their ideas. This is consistent with Shea's (1995) study, which pointed out that stronger members may overpower weaker members and monopolize the discussion.

In response to these problems, and as suggested by Chisholm (1990), teachers must ensure that students' understand their roles during the collaborative task and that group members perform their responsibilities successfully.

2. Students' proficiency in English. According to $62 \%$ of the subjects, group members discussed their ideas in Arabic, which reduced the chances of improving their communication skills. It is suggested that students' lack of proficiency in the second language may encourage them to use their first language to express their ideas, which offsets the benefits of the collaborative task. Hence, it is important for the students to understand the benefits of the collaborative dialogue on their language learning and they should be encouraged to give their peers the time they need to express themselves.

3. Time management. In contrast to Speck (2002), who suggested that collaborative writing is time-consuming, the data from the questionnaire showed that there is a disagreement on whether collaborative writing took a lot of time ( $40 \%$ agreed, while $38 \%$ disagreed). One reason might be the students' attitude during the task, which may increase or decrease the time of the activity. A group of students who are willing to discuss and exchange ideas may take more time than a group of passive students who are unwilling to engage in discussions. Furthermore, students with high standards 
may need more time to produce a well-written text. However, one benefit of the collaborative work could be improving students' time management skills.

\section{CONCLUSION}

The present study aimed to investigate Saudi female EFL learners' attitude toward collaborative writing and the challenges/problems that may arise during the activity. The findings confirm that students believe that collaborative writing can be a useful strategy to improve their language skills in general and their writing skills in particular. It can also increase their motivation, improve their communication and negotiation skills, and stimulate critical thinking. These results tie in well with previous studies that stressed the importance of collaborative writing (Elola \& Oskuz, 2010; Storch \& Wigglesworth, 2007). However, the findings confirm that some problems may arise during collaborative writing. These problems are mainly related to students' behavior. This is consistent with research investigating issues in collaborative writing (Shea, 1995). However, based on students' positive attitude toward collaborative writing and its benefits, collaborative writing should be integrated into the writing curriculum. Moreover, the benefits of the task and the roles and responsibilities of the students must be clarified (Chisholm, 1990). Finally, teachers and researchers must address the problems that arise during the collaborative task to ensure that the activity achieve its goals.

Limitations and recommendations

One of the limitations of the present study is the small sample size, which affects the generalization of the results. Another limitation is that the study did not consider the subjects' proficiency level in English in general and in their writing skills in particular, which might affect their attitude and their engagement in the task. The third limitation is that the study only uses one instrument, the questionnaire. Using other instruments such as interviews may provide more data.

The same study should be carried out with a larger number of students, taking into consideration their language proficiency level. Another study can be carried out with male students to investigate whether different genders have different attitudes toward writing collaboratively. Another study can be conducted to investigate problems of collaborative writing from teachers' perspective.

\section{APPENDIX}

This questionnaire is a part of a study that investigates Saudi female EFL learners' attitude toward collaborative writing. Your response and time are highly appreciated.

\begin{tabular}{|c|c|c|c|}
\hline Statement & Agree & Neutral & Disagree \\
\hline \multicolumn{4}{|l|}{$\begin{array}{l}\text { Collaborative writing is an effective strategy that results in better, more accurate and complex } \\
\text { essays. }\end{array}$} \\
\hline \multicolumn{4}{|l|}{ Collaborative writing makes the task more enjoyable and interesting, and motivates to write } \\
\hline \multicolumn{4}{|l|}{ Expressing my ideas to the group improves my communication and negotiation skill. } \\
\hline \multicolumn{4}{|l|}{$\begin{array}{l}\text { Collaborative writing helps me learn how to plan, organize, and structure the essay more } \\
\text { effectively. }\end{array}$} \\
\hline \multicolumn{4}{|l|}{ Collaborative writing helps in improving my writing skill in general. } \\
\hline \multicolumn{4}{|l|}{$\begin{array}{l}\text { Collaborative writing helps in understanding and considering multiple viewpoints on a } \\
\text { particular topic. }\end{array}$} \\
\hline \multicolumn{4}{|l|}{ Collaborative writing helps in constructing a strong argument. } \\
\hline \multicolumn{4}{|l|}{ Collaborative writing helps me verbalize and explain my ideas. } \\
\hline \multicolumn{4}{|l|}{$\begin{array}{l}\text { Collaborative writing stimulates critical thinking skills (through commenting on others' } \\
\text { ideas). }\end{array}$} \\
\hline \multicolumn{4}{|l|}{ In collaborative writing, everyone performs an equal amount of work. } \\
\hline \multicolumn{4}{|l|}{ Collaborative writing helps in improving grammatical accuracy and learning vocabulary. } \\
\hline \multicolumn{4}{|l|}{ Collaborative writing helps me receive useful feedback. } \\
\hline \multicolumn{4}{|l|}{ It is unfair that all the members get the same grade. } \\
\hline \multicolumn{4}{|l|}{ Some members do not accept opposing opinions. } \\
\hline \multicolumn{4}{|l|}{$\begin{array}{l}\text { Some members control the discussion without giving others an opportunity to explain their } \\
\text { ideas. }\end{array}$} \\
\hline \multicolumn{4}{|l|}{ Collaborative writing consumes a lot of time. } \\
\hline $\begin{array}{l}\text { Members discuss their ideas in Arabic, which decreases the chances of improving } \\
\text { communication skill. }\end{array}$ & & & \\
\hline
\end{tabular}

\section{REFERENCES}

[1] Abdel, M., \& Farrah, H. (2015). Online Collaborative Writing: Students' Perception. Journal of Creative Practices in Language Learning and Teaching (CPLT), 3(2), 17-32.

[2] Al Ajmi, A. A., \& Ali, H. I. (2014). Collaborative writing in group assignments in an EFL/ESL classroom. English Linguistics Research, 3(2), 1-17. https://doi.org/10.5430/elr.v3n2p1. 
[3] Aminloo, M. S. (2013). The effect of collaborative writing on EFL learners writing ability at elementary level. Journal of Language Teaching and Research, 4(4). doi:10.4304/jltr.4.4.801-806.

[4] Bilal, H. A., Tariq, A., Din, N., Latif, H., \& Anjum, M. N. (2013). Investigating the problems faced by the teachers in developing English writing skills. Asian Journal of Social Sciences \& Humanities, 2(3), 238-244. Retrieved in June, 2020 from http://www.ajssh.leena-luna.co.jp/AJSSHPDFs/Vol.2(3)/AJSSH2013(2.3-27).pdf.

[5] Bueno-Alastuey, M. A., \& Larumbe, P. M. (2017). Collaborative writing in the EFL secondary education classroom: comparing triad, pair and individual work. Huarte de San Juan Filologíay Didáctica de la Lengua, 17, 254-275. Retrieved in June, 2020 from https://academicae.unavarra.es/bitstream/handle/2454/28503/HSJ_Filolog\%C3\%ADa_17_2017_Collaborative.pdf? sequence=1\&isAllowed=y.

[6] Brown, H. D. (1994). Teaching by principles: An interactive approach to language pedagogy. Upper Saddle River: Prentice Hall Regents.

[7] Bruffee, K. A. (1984). Collaborative learning and the conversation of mankind. College English, 46, 635-652. Retrieved in June, 2020 from https://www.jstor.org/stable/376924?seq=1\#page_scan_tab_contents.

[8] Casanave, C. P. (2004). Controversies in second language writing. Ann Arbor, MI: The University of Michigan Press.

[9] Castro, C. M., \& Chala, P. A. (2013). Undertaking the act of writing as a situated social practice: going beyond the linguistic and the textual. Colomb. Appl. Linguist. J, 15(1), 25-42. Retrieved in June, 2020 from http://www.scielo.org.co/pdf/calj/v15n1/v15n1a2.pdf.

[10] Chala, P. A., \& Chapetón, C. M. (2012). "EFL argumentative essay writing as a situated-social practice: A review of concepts". Folios, 1(36), 23-36. Retrieved in June, 2020 https://doi.org/10.17227/01234870.36folios 23.36.

[11] Chandra, R. (2015). Collaborative learning for educational achievement. IOSR Journal of Research \& Method in Education, 5(2), 1-4. doi: 10.9790/7388-052XXXXX.

[12] Chisholm, R. M. (1990). Coping with problems of collaborative writing. Writing across the curriculum, 11, 90-108. Retrieved in June 2020 from https://wac.colostate.edu/docs/journal/vol2/chisholm.pdf.

[13] Choi, J. W. (2008). The role of online collaboration in promoting ESL writing. English Language Teaching, 1(1). doi:10.5539/elt.v1n1p34.

[14] Crandall, J. (1999). Cooperative language learning and affective factors. In Arnold, J (Eds.) Affect in Language Learning. Cambridge University Press. Beijing: Foreign language Teaching and Research Press, 2000.

[15] Davies, W. M. (2009). Groupwork as a form of assessment: Common problems and recommended solutions. Higher Education, 58(4), 563-584. https://doi.org/10.1007/s10734-009-9216-y.

[16] Deane, P., Odendah, N., Quinlan, T., Fowles, M., Welsh, C., \& Tatum, J. (2008). Cognitive models of writing: writing proficiency as a complex integrated skill. Princeton, NJ: ETS.

[17] Deveci, T. (2018). Student perceptions on collaborative writing in a project-based course. Universal Journal of Educational Research, 6(4), 721-732. doi:10.13189/ujer.2018.060415.

[18] Dobao, A. F. (2012). Collaborative writing tasks in the L2 classroom: Comparing group, pair, and individual work. Journal of Second Language Writing, 21(1), 40-58. Retrieved in June, 2020 from https://www.sciencedirect.com/science/article/abs/pii/S106037431100066X?via\%3Dihub.

[19] Dobao, A., Blum, A. (2013). Collaborative writing in pairs and small groups: learners' attitudes and perceptions. System, 41, 365-378. http://dx.doi.org/10.1016/j.system.2013.02.002.

[20] Dueraman, B. (2012). Teaching EFL writing: Understanding and rethinking the Thai experience. Journal of Alternative Perspectives in the Social Sciences, 4(1), 255-275. Retrieved in June, 2020 from https://www.academia.edu/4513345/Teaching_EFL_writing_Understanding_and_Re-thinking_the_Thai_Experience.

[21] Elbow, P. (2000). Everyone can write: Essays toward a hopeful theory of writing and teaching writing. Oxford University Press.

[22] Ellis, R. (2003). Task-based language learning and Teaching. Oxford: Oxford University Press.

[23] Ellis, R. (2008). The study of second language acquisition $\left(3^{\text {rd }}\right.$ ed.). Oxford: Oxford University Press.

[24] Elola, I., \& Oskoz, A. (2010). Collaborative writing: fostering foreign language and writing conventions development. Language Learning \& Technology, 14, 51-71. Retrieved in June, 2020 from https://core.ac.uk/download/pdf/26920581.pdf.

[25] Farrah, M. A. (2011). Attitudes towards collaborative writing among English majors in Hebron University. AWEJ, 2(4), 136170. $\quad$ Retrieved in $\quad$ June, 2020 from https://www.academia.edu/18095021/Attitudes_Towards_Collaborative_Writing_Among_English_Majors_in_Hebron_Univer sity.

[26] Fareed, M., Ashraf, A., \& Bilal, M. (2016). ESL learners' writing skills: Problems, factors and suggestions. Journal of Education \& Social Sciences, 4(2), 83-94. https://doi.org/10.20547/jess0421604201.

[27] Ghufron, M. A., \& Hawa, M. (2015). The effect of collaborative writing technique in teaching argumentative essay writing viewed from the students' creativity. Journal of Language and Literature, 10(1), 49-60. Retrieved in June, 2020 from https://journal.unnes.ac.id/nju/index.php/LC/article/view/4158.

[28] Gökçe, I. (2001). Effect of collaborative writing on attitudes of learners towards writing at Anadolu University Preparatory School (master's thesis). Bilkent University, Turkey.

[29] Harmer, J. (2007). The Practice of English Language Teaching, 4th ed., Harlow, Pearson.

[30] Hernández, R. (2012). Collaborative learning: Increasing students' engagement outside the classroom. US-China Education Review, 9, 804-812. Retrieved in June, 2020 from https://files.eric.ed.gov/fulltext/ED537177.pdf.

[31] Hidayati, K. H. (2018). Teaching writing to EFL learners: An investigation of challenges confronted by Indonesian teachers. Journal for the association for Arabic and English, 4(1), 21-31. Retrieved in June, 2020 from http://ejournal.iainkendari.ac.id/langkawi/article/view/772.

[32] Isnaini, M. H. (2017). The effectiveness of collaborative work in developing students L2 writing achievement across social orientation. Language in India, 17(5), 84-104. Retrieved in June, 2020 from http://www.languageinindia.com/may2017/isnainicollaborativewriting.pdf. 
[33] Koura, A. A., \& Zahran, F. A. (2017). Using habits of mind to develop EFL writing skills and autonomy. Arab World English Journal, 8(4), 183-198. doi: https://dx.doi.org/10.24093/awej/vol8no4.12.

[34] Kowal, M., \& Swain, M. (1994). Using collaborative language production tasks to promote students' language awareness. Language Awareness, 3, 73-93. Retrieved in June, 2020 from https://www.tandfonline.com/doi/abs/10.1080/09658416.1994.9959845.

[35] Kraut, R. E., Galegher, J., \& Egido, C. (1987). Relationships and tasks in scientific research collaboration. Human-Computer Interaction, 3(1), 31-58. https://doi.org/10.1207/s15327051hci0301.

[36] Laal, M., \& Ghodsi, S. M. (2012). Benefits of collaborative learning. Procedia - Social and Behavioral Sciences, 31, $486-490$. Retrieved in June, 2020 from https://doi.org/10.1016/j.sbspro.2011.12.091.

[37] Liang, X., Mohanf, B. A., \& Early, M. (1998). Issues of cooperative learning in ESL classes: A literature review. TESL Canada Journal, $15(2), \quad 13-23 . \quad$ Retrieved in June, 2020 from http://citeseerx.ist.psu.edu/viewdoc/download?doi=10.1.1.1021.613\&rep=rep1\&type=pdf.

[38] Lin, O. P., \& Maarof, N. (2012). Collaborative writing in summary writing: student perceptions and problems. Procedia Social and Behavioral Sciences, 90, 599 - 606. doi: 10.1016/j.sbspro.2013.07.131.

[39] Louth, R., McAllister, C., \& McAllister, H. A. (1993). The effects of collaborative writing techniques on freshman writing and attitudes. The Journal of Experimental Education, 61(3), 215-224. Retrieved in June, 2020 from https://www.jstor.org/stable/20152373?seq=1\#page_scan_tab_contents.

[40] Megnafi, S. (2015). Teaching writing through collaborative activities: the case of first year students at University of Tlemcen (master's thesis). University of Tlemcen, Algeria.

[41] Narayan, R., \& Johnson, L. (n.d). How to solve common team writing problems. Retrieved in June, 2020 from https://www.engineering.uiowa.edu/sites/www.engineering.uiowa.edu/files/wysiwyg_uploads/ctc_guide_how_to_solve_comm on_team_writing_problems.pdf.

[42] Nurfaidah, S. (2018). Vygotsky's legacy on teaching and learning writing as social process. Journal for the association for Arabic and English, 4(2). 149-156. Retrieved in June, 2020 from https://www.researchgate.net/publication/330013861_Vygotsky's_Legacy_on_Teaching_and_Learning_Writing_as_Social_Pr ocess.

[43] Richard, J. C. (1990). The Language teaching matrix. New York: Cambridge University Press.

[44] Salma, U. (2015). Problems and practical needs of writing skill in EFL context: an analysis of Iranian students of Aligarh Muslim University. Journal of Humanities and Social Science, 20(11), 74-76. Retrieved in June, 2020 from http://www.iosrjournals.org/iosr-jhss/papers/Vol20-issue11/Version-3/L0201137476.pdf.

[45] Slavin, R. E. (2011). Instruction Based on Cooperative Learning. In R. E. Mayer \& P. A. Alexander (Eds.), Handbook of research on learning and instruction (pp. 344-360). New York: Taylor \& Francis.

[46] Sharon, S., Bejarano, Y., Kussell, P., \& Peleg, R. (1984). Achievement in English language and in literature. In S. Sharan, P. Kussell, R. Hertz-Lazarowitz,Y. Bejarano, S. Raviv, \& Y. Sharan (Eds.), Cooperative learning in the classroom: Research in desegregated schools (pp. 46-72). Hillsdale, NJ: Erlbaum.

[47] Shea, J. H. (1995) Problems with collaborative learning. Journal of Geological Education, 43(4), 306-308. Retrieved in June 2020 from https://www.tandfonline.com/doi/abs/10.5408/0022-1368-43.4.306.

[48] Shehadeh, A. (2011). Effects and student perceptions of collaborative writing in L2. Journal of Second Language Writing, 20, 286-305. http://dx.doi.org/10.1016/j.jslw.2011.05.010.

[49] Speck, B. W. (2002). Facilitating students' collaborative writing. California: Jossey-Bass.

[50] Storch, N. (2002). Patters of interaction in ESL pair work. Language learning, 52, 119-158. Retrieved from https://www.academia.edu/17262823/Patterns_of_Interaction_in_ESL_Pair_Work.

[51] Storch, N. (2005). Collaborative writing: Product, process, and students' reflections. Journal of Second Language Writing, 14 , 153-173. doi:10.1016/j.jslw.2005.05.002.

[52] Storch, N. \& Wigglesworth, G. (2007). Writing tasks: The effects of collaboration. In M. P. García Mayo (Ed.), Investigating Tasks in Formal Language Learning (pp. 157-177). Clevedon, UK: Multilingual Matters.

[53] Storch, N., \& Aldosari, A. (2010). Learners' use of first language (Arabic) in pair work in an EFL class. Language Teaching Research, 14(4), 355-375. http://dx.doi.org/10.1177/1362168810375362.

[54] Stuyf, R. R. (2002). Scaffolding as a teaching strategy. Retrieved from http://workplacesafety.pbworks.com/f/Scaffold\%20Learning.doc.

[55] Supiani, (2017). Teaching writing skill through collaborative writing technique from theory to practice. JEELS, 4(1), 37-52. Retrieved from https://media.neliti.com/media/publications/135563-EN-teaching-writing-skill-through-collabora.pdf.

[56] Swain, M. (1985). Communicative competence: Some roles of comprehensible input and comprehensible output in its development. In S. Gass, \& C. Madden (Eds.), Input in second language acquisition (pp. 235-253). Rowley, MA: Newbury House.

[57] Swain, M. (2000). The output hypothesis and beyond. In J. Lantolf (Ed.), Sociocultural theory and second language acquisition (pp. 97-114). Oxford, UK: Oxford University Press.

[58] Swain, M., \& Lapkin, S. (1998). Interaction and second language learning: Two adolescent French immersion students working $\begin{array}{lllll}\text { together. The } \quad \text { Modern } & \text { Language Journal, } & \text { 320-337. Retrieved from }\end{array}$ https://www.academia.edu/38342610/Interaction_and_Second_Language_Learning_Two_Adolescent_French_Immersion_Students_Working_together.pdf.

[59] Tarmizi, T., \& Cheung, Y. L. (2017). Collaborative writing in classroom instruction: A synthesis of recent research. The English Teacher, 46(2), Retrieved 43-57. https://www.researchgate.net/profile/Yin_Ling_Cheung_nanyang_Technological_University/publication/319930154/inline/jsV iewer/59c1f4b4458515af305c8eb8.

[60] Tessema, A. K. (2005). Simulating writing project-based tasks. English Teaching Forum, 43(4), 22-28. Retrieved in June, 2020 from https://americanenglish.state.gov/files/ae/resource_files/tessema_-_forum_.pdf. 
[61] Vygotsky, L. (1978). Mind in society. Cambridge: Harvard University Press.

[62] Weinstein, B. D., \& Bearison, D. J. (1985). Social interaction, social observation, and cognitive development in young children. European Journal of Social Psychology, 15(3), 333-343. Retrieved in June 2020 fromhttps://www.google.com/amp/s/www.researchgate.net/publication/230115659_Social_int eraction_social_observation_and_cognitive_development_in_young_children/amp.

[63] Wheaton College. (n.d). Style, diction, tone, and voice. Retrieved in June 2020 from https://www.wheaton.edu/academics/services/writing-center/writing-resources/style-diction-tone-and-voice/.

[64] Wigglesworth, G., \& Storch, N. (2009). Pair versus individual writing: Effects on fluency, complexity and accuracy. Language Testing, 26(3), 445-466. Retrieved from https://journals.sagepub.com/doi/10.1177/0265532209104670.

[65] Wigglesworth, G., \& Storch, N. (2012). What role for collaboration in writing and writing feedback? Journal of Second Language Writing, 21, 364-374. http://dx.doi.org/10.1016/j.jslw.2012.09.005.

[66] Wojahn, P. G., Blicharz, K. A., \& Taylor, S. K. (2010). Engaging in virtual collaborative writing. Virtual Collaborative Writing in the Workplace, 65-87. https://doi.org/10.4018/978-1-60566-994-6.ch004.

[67] Wu, H. J. (2015). The effects of blog-supported collaborative writing on writing performance, writing anxiety and perceptions of EFL college students in Taiwan (doctoral dissertation). University of South Florida, Tampa, FL, USA.

[68] Zhang, Y. (2010). Cooperative Language Learning and Foreign Language Learning and Teaching. Journal of Language Teaching and Research, 1(1), 81-83. doi:10.4304/jltr.1.1.81-83.

Nada Abdulaziz Alkhalaf is from Saudi Arabia. She was born on 17-4-1990. She obtained a BA degree with honor from Qassim University in English Language in 2012. She is currently an MA student at Applied Linguistics program at College of Arabic Language and Social Studies, Qassim University, Saudi Arabia. She is a lecturer at the Department of English language and Translation in Qassim University. 